\title{
Mycenaean pottery from Amara West (Nubia, Sudan)
}

Michela Spataro $^{1 *}$, Anna Garnett ${ }^{2}$, Andrew Shapland $^{1}$, Neal Spencer ${ }^{1}$ and Hans Mommsen ${ }^{3}$

1. British Museum, Great Russell St, London WC1B 3DG

*Email address: michelaspataro@yahoo.co.uk; mspataro@thebritishmuseum.ac.uk

t. $+44(0) 2073238342$

2. The Petrie Museum of Egyptian Archaeology, University College London, Malet Place, London WC1E 6BT

3. Helmholtz-Institut für Strahlen- und Kernphysik, Rheinische Friedrich-Wilhelms-Universität Bonn, Nussallee $14-16,53115$ Bonn

\begin{abstract}
Amara West, built around 1300 BC, was an administrative centre for the pharaonic colony of Upper Nubia. In addition to producing hand- and wheel-made pottery, respectively in Nubian and Egyptian style, Amara West also imported a wide range of ceramics from Egypt and the eastern Mediterranean. A scientific of 18 Mycenaean style ceramics was undertaken to study provenance and aspects of production technology. Neutron activation analyses (NAA) results show that the pots were imported from several workshops in in Greece and Cyprus. Thin section petrography and scanning electron microscopy, used with energy dispersive spectroscopy (SEM-EDX), show that different recipes were used to make the fabrics and paints of Mycenaean ceramics, reflecting both technological choices and the range of raw materials used in the different workshops. The petrographic and SEM-EDX results support the NAA provenance attributions.
\end{abstract}

Keywords: Mycenaean pottery, Amara West, thin sections, NAA, SEM-EDX, ceramic technology

\section{Introduction}

The site of Amara West, located on the left (north) bank of the River Nile in Sudan, was built around $1300 \mathrm{BC}$ as a new administrative centre for the pharaonic colony of Upper Nubia (Kush). Excavations have revealed a temple, storage facilities, housing and industrial areas, with cemeteries located north of the town, across a now-dry river channel (Spencer 1997, 2002; Spencer 2014, 2015; Figure 1). The ceramic assemblage from Amara West includes Nubian (hand-made) and Egyptian (predominantly wheel-made) Nile silt vessels, produced using local raw materials, in addition to imports from Egypt, the Near East and the Mediterranean (Spataro et al. 2015). This paper focuses on the Mycenaean vessels produced in the Aegean and on Cyprus in the Late Bronze Age.

Fragments of Mycenaean pottery were excavated at Amara West by the Egypt Exploration Society 
[EES] (in 1938-9 and 1947-50; Spencer 1997, pp. 38-39; pl. 56-57, col. pl. 2a) and the British Museum (in 2009-2015). Unlike artefacts from modern excavations in Egypt, the Mycenaean sherds British Museum, while those excavated by the British Museum were exported to the UK for study with the permission of the National Corporation for Antiquities and Museums (Sudan). A range of petrographic and chemical techniques could then be applied to these sherds in order to characterise the Mycenaean pottery traded along the Nile at this period, providing insights into the social and technological perspectives of the trade.

\section{Mycenaean vessels in Egypt and Nubia}

Mycenaean pottery has been identified in both settlement and cemetery contexts at New Kingdom (c. 1550-1070 BC) sites from the Nile Delta to Nubia (van Wijngaarden 2011). Most examples date to the Late Helladic (LH) IIIA-B periods (fourteenth-thirteenth centuries BC) and comprise closed forms, particularly stirrup jars and pilgrim flasks. These shapes were used as containers for olive oil, perhaps perfumed. Smaller assemblages almost invariably contain fragments of these closed forms, pointing to the sporadic import and use of perfumed oil and/or re-use of the vessels. Larger assemblages, particularly those from the royal cities of Amarna (Hankey 1997) and Qantir (Mountjoy and Mommsen 2001), comprise a wider diversity of shapes, including open forms associated with drinking, not attested at Amara West. At Amarna, as elsewhere in Egypt, Mycenaean sherds were found in a wide variety of social contexts (van Wijngaarden 2011, pp. 237-9).

There are fewer Mycenaean imports in Nubia than Egypt, and no open vessel fragments, with stirrup jars and flasks known from Buhen (Emery et al. 1979, p. 185), Sai (Minault-Gout and Thill 2012, p. 369, pl. 145, 161), Tombos (Smith 2003, p. 152, fig. 6.21) and Sesebi (Fairman 1938, p. 152), and an unusually-decorated Late Minoan alabastron from Aniba (Steindorff 1937, pp. 139-41).

\section{Mycenaean vessels at Amara West}

The Amara West assemblage consists of 27 sherds from closed vessels, eighteen of which are analysed here (Table 1). Joining sherds were restored before sampling but two near joins were subsequently identified, meaning that in two cases parts of the same vessel were sampled twice. Shapes (denoted FS) are described using Furumark's (1941) classification. In Aegean ceramic terms, the sherds date from LHIIIA2 (1375-1300 BC) to LHIIIB (1300-1200 BC).

The majority are individual sherds that may reflect secondary deposition and thus are unlikely to relate to the use contexts of the vessels. Only two sherds were found in the Residence of the Deputy of Kush, the highest pharaonic official at the site (739a, Spencer 2002, p. 38, pl. 57; obj. 909, Spencer 1997, p. 230) and another outside the temple forecourt (AW227); four were found in deposits within storage magazines (AW212, AW225, AW226, and C9339). These are all within spaces one might assume were controlled by the town's administration. Rather more sherds have been found in small houses, in contexts predating phase III (which starts around 1180BC); the sherd found in the western suburb 
(C9493) is from a midden deposit most likely relating to pre-phase III activity inside the walled town. Only one sherd (C9512) comes from a phase III (or later) deposit, suggesting that such vessels were

rarer still in the later periods of occupation, mirroring the fall-off in their circulation within Egypt (Figure 2). Another factor might be the change in character of the town, away from being a state foundation to one shaped by its inhabitants, with explicit Nubian cultural elements-architecture, funerary customs and ceramics_-becoming more visible (see Spencer 2017). Van Wijngaarden (2011, p. 241) refers to the attraction of small Mycenaean storage vessels within Egypt for the "perception of foreignness"; at Amara West, we must also ask whether such vessels were seen as distinct from other imports coming from Egypt.

Two of the scattered sherds almost certainly derive from the same pilgrim flask (AW213 and AW214, FS 189), an LHIIIA2 form. This was the most common shape imported to Amarna (Hankey 1997, p. 205), several decades before Amara West was founded. Excavations at Qantir mostly yielded stirrup jars, although these are generally later in date than those from Amara West despite the sites being founded within a short time of each other (Mountjoy and Mommsen 2001, p. 143); the remaining individual Amara West sherds can be identified as variants of the stirrup jar form, which in the absence of distinctive decorative features cannot be dated more closely than late LHIIIA2/LHIIIB. Most are embellished with lustrous paint in thick and thin linear bands, pointing to manufacture on the Greek mainland. Two small matt-painted examples can be assigned to the 'Simple Style' and were made on Cyprus, as discussed below.

The most informative context for such vessels at Amara West is the deposit within a modest house (D13.4, see Spencer 2017, 337-40) that dates to shortly after the town was founded (see Figure 2 and Table 1) which yielded two stirrup jars crushed side-by-side and fragments of others. One represents a form (AW216, AW218; Figure 3) decorated with simple linear bands typically dated to LHIIIA2 (FS 178, see Leonard 1994, 59) and the other, a slightly flatter example (AW219, FS 180) decorated with the 'multiple stem' motif in the shoulder zone and with concentric circles painted on the base, can be dated to LHIIIB (Mountjoy 1986, p. 108). As the Amara West deposit is securely dated to $1300 \mathrm{BC}$ or shortly afterward, it coincides with the transition between LHIIIA2 and LHIIIB. The presence of the two vessel types therefore suggests vessels from these different ceramic periods were in circulation together.

Finally, none of the burials at Amara West were accompanied by Mycenaean pottery, in contrast to the examples found within the New Kingdom tombs at Tombos, further upstream in Nubia (Smith 2003, p. 152, fig. 6.21).

\section{Production and trade}

Scientific analyses of Mycenaean pottery, particularly Neutron Activation Analysis (NAA), have shown that there were different production places, including some outside Greece. A recent programme of NAA testing on samples from Cyprus has allowed particular production centres to be identified on the island, both for so-called 'Simple Style', which has only linear decoration, and other Mycenaean pottery types (Mountjoy and Mommsen 2015); the same technique has shown most Mycenaean vessels found in 
Egypt were made in Greece, but with a small number produced in Cyprus and in Egypt itself (Mommsen et al. 1992; Mountjoy and Mommsen 2001, pp. 138-139).

Some types were produced in Greece for export to the Eastern Mediterranean (van Wijngaarden 2002), with vessels arriving in Egypt via shipments combining a range of raw materials, produce and objects, encompassing official exchange but also the activities of merchants and other individuals (Kelder 2010; van Wijngaarden 2011). It is likely that a small number of these fine vessels were then conveyed to Nubian sites such as Amara West as part of direct or indirect trade or supply from sites in Egypt proper. Elephantine, at the southern edge of pharaonic Egypt, has long been assumed to have been an entrepôt for supplying Nubian military campaigns, and evidence from sites such as Sai suggest a role in supplying pottery (Budka 2015, pp. 50-1). These important Nubian towns also received visits from elite officials, notably the Viceroy of Kush, at which time statuary and other monuments were dedicated (Müller 2013): could the donation of exotic Mycenaean flasks and jars have occurred in such contexts? Alternatively, it is possible that vessels arrived in Nubia before the foundation of Amara West, and were brought to the town by those relocated from existing pharaonic towns such as Sai, as occurred with papyrus documents (suggested by seal impressions) and portable inscribed stone monuments (Spencer 1997, pp. 247-8).

Our understanding about production places and, to a lesser extent, exchange methods, provides a framework for the analyses presented here, the first such study of Mycenaean pottery from Sudan.

\section{Methods}

Eighteen potsherds were sampled to determine provenance, identify mineralogical variations, and understand the manufacturing technique. For provenance, NAA was carried out at the Rheinische Friedrich-Wilhelms-Universität Bonn (following Mommsen et al. 1991, Mommsen 2011). Powdered samples of around $80 \mathrm{mg}$ were taken by drilling with a corundum drill bit and were later irradiated at the research reactor of the Reactor Institute Delft and, after four week measurements in the Bonn laboratory, quantitative weight concentrations were determined using the Bonn pottery standard (Mommsen and Sjöberg 2007). Petrographic thin sections were analysed at the British Museum using a Leica DMRX polarised light microscope. A Hitachi S-3700N variable pressure (VP) scanning electron microscope fitted with an Oxford Instruments AZtec energy dispersive X-ray spectrometry (SEM-EDX) was used to study the microstructure and chemical composition of ceramic fabrics. Four bulk analyses c. of areas $c .1 .4 \times 1.0 \mathrm{~mm}$ were carried out on each sample, using Oxford Instruments standards and checked against the Corning A glass standard. Ten elements (Na, Mg, Al, Si, P, K, Ca, Ti, Mn, Fe) were quantified; the results were converted into oxide percentages, which were normalised (oxygen by stoichiometry) to account for the fact that oxygen and carbon are not measured (e.g. Spataro et al. 2015, pp. 177-183).

Principal component analysis (PCA) was used to help interpret the SEM-EDX results. PCA of the correlation matrix was performed using PAST v.3.04 (Hammer et al. 2001). All principal components were examined. Patterning in the SEM-EDX results was compared to source attributions based on NAA trace element data. 
Elemental maps of the red paints on samples AW221 and AW228 were acquired by overnight SEMEDX analysis, as the EDX chemical compositions of the very thin superficial layers of colour identified in thin section were different from each other. In addition, an EDX elemental map of the surface of sample AW227 was acquired, to determine whether the distribution of potassium, which is concentrated in the red colour, might have been partly due to the fuel type used.

\section{Results \\ Petrographic analysis}

Without reference to NAA and EDX data, the Mycenaean samples were divided into six calcareous petro-fabric groups (Table 2). Petro-fabric 1 is very fine, highly-fired with occasional and fine inclusions, and ferruginous pellets. Petro-fabric 2 is more micaceous with occasional carbonates, and ferruginous pellets as in petro-fabric 1. Petro-fabric 3 contains abundant fine limestone fragments, coarser quartz sand and more iron-rich clay pellets than petro-fabrics 1 and 2. Petro-fabrics 4-6 are fossiliferous with recurrent foraminifera. Fabrics 4 and 5 are finer than 6, which contains coarser limestone fragments than the other groups, and whose clay was less well-processed. By polarised microscopy, it can be seen that the glossy surfaces on all samples were obtained by polishing the leather-dry clay before firing, and not by coating with a slip.

\section{$S E M-E D X$}

SEM microscopy was used to estimate firing temperature and investigate the microstructure of paints used to decorate the ceramics. Vitrified clay filaments in petro-fabric 1 samples (Figure 4) indicate firing temperatures higher than $850-900^{\circ} \mathrm{C}$; other fabrics were fired at $<750-800^{\circ} \mathrm{C}$, as the pastes are not vitrified and the chamber walls of microfossils are intact (Figure 5; see Kilikoglou 1994). The paints are extremely fine and almost inclusion-free.

SEM-EDX results (Table 3) show that petro-fabrics 1, 2 and 3 are chemically fairly similar. Only potash contents are rather variable $(0.9-3.1 \%)$; the other oxides vary within relatively narrow ranges. The compositions of fabrics 4-6 are different to each other and to those of fabrics 1-3. SEM-EDX was also used to analyse the paint on eight potsherds (Table 4). Three bulk analyses per sample were carried out at high magnification $(c . \times 1.0 \mathrm{k})$. The results from the paint align with the petro-fabrics. The pigments of petro-fabrics 5 and 6 are clearly different to each other and to those from petro-fabrics $1-3$, with higher soda, magnesia and iron oxide and lower potash and alumina. In addition, elemental maps were obtained of the section (Figure 6) and surface (Figure 7) of AW227.

The surface map shows that high potassium is an intrinsic component of the pigment and is not derived from firing, as potassium is much lower on the undecorated surface of the vessel than in the pigmented area. High levels of potassium in Greek Bronze Age pottery may result from using well-levigated illitic clay as paint (Noll et al. 1975, p. 607). Although the potassium contents for the Amara West paint samples (Table 4) fall within the ranges reported by Buxeda i Garrigós et al. (2002, p. 274), based on SEM-EDX data from Mycenaean pottery found in Greek Macedonia, the iron contents are apparently lower.

NAA results 
Statistical analysis of the NAA results, carried out with the statistical procedure developed in Bonn (Beier and Mommsen 1994) attributed sixteen of the eighteen samples to five groups, with two

indeterminate results (Appendix 1). Fourteen were attributed to the group MYBE and two of its subgroups (MBKR, MBKK) with very similar patterns associated with an origin from the northeastern Peloponnese (Table 1).

A provenance attribution of groups MYBE and its subgroups to only the region of Mycenae/Berbati or the Argolid is no longer sustainable, since vessels from Corinthia are known with these patterns (Mommsen et al. 2016). Samples of the subgroup MBKR compare to the main core group MYBE, with slightly lower concentration values of the elements $\mathrm{K}$ and $\mathrm{Rb}$, whereas subgroup MBKK has still lower concentrations of these elements. One sample (AW211) was attributed to the OlyA (Achaia/Elis), with a lower, but not negligible, probability that it could be assigned to the MBKR sources, also in the Peloponnese. Two samples were attributed to Cyprus, one (AW221) to the CypJ group from Kition/Hala Sultan Tekke (Mountjoy and Mommsen 2015, p. 425) and the other (AW212) was indeterminate, but most likely Cypriot, although not assigned to a specific group. The last sample (AW223) could not be matched to any known sources. Figure 8 shows the result of a discriminant analysis of the 18 samples from Amara West assuming 3 groups and including the four chemical single vessels. The main group MYBE is well separated from its subgroups MBKR and MBKK and also from the single pieces.

\section{Discussion}

The Mycenaean imports in circulation at Amara West clearly came from several different workshops. Six calcareous fabrics were identified by optical microscopy, representing different clay sources or clay preparation methods. NAA results associate petro-fabrics 1-3 with Peloponnesian sources, whereas the three sherds of petro-fabrics 4-6 are sufficiently different to the Peloponnesian material, and to each other, to represent different clay sources.

Petro-fabrics 1 and 2 are chemically similar in terms of the concentration of the major and minor oxides measured by SEM-EDX (Figure 8), consistent with the trace element analysis attribution of these sherds to the northeastern Peloponnese. They were more highly-fired than the other samples analysed, at temperatures exceeding $850-900^{\circ} \mathrm{C}$. They differ in the extent of levigation (refining by suspension in water): the clay of petro-fabric 1 was carefully levigated, whereas petro-fabric 2 is slightly more micaceous, with occasional naturally occurring calcareous fragments. The two fragmentary stirrup jars (AW 216/218 and AW219) belong to petro-fabric 1 and the same NAA group (MYBE). The majority of the other Mycenaean potsherds from the site also belong to petro-fabric 1, and are distributed between three related NAA groupings (which are reflected in SEM-EDX data: in Figure 9, petro-fabric 1 sample scores on principal component 2 correspond to the main NAA group and its two subgroups with decreasing $\mathrm{K}$ and $\mathrm{Rb}$ concentrations).

Petro-fabric 2 is represented by two sherds (AW213 and AW214), almost certainly from the same pilgrim flask, as indicated by the similarity of decoration and near join. They gave very similar SEMEDX results and were also allocated to the same NAA subgroup MBKR of group MYBE. Petro-fabric 2 could be regarded as incompletely levigated and homogenised clay from the same source as petro-fabric 1. 
Sample AW211 (petro-fabric 3) was not distinguishable from petro-fabrics 1 and 2 using the SEM-EDX data but was produced using a coarser, non-levigated, raw material, richer in quartz and limestone fragments, than petro-fabrics 1 and 2. This sherd belonged to the OlyA group, from the area of Achaia/Elis in the northwestern rather than the northeastern Peloponnese according to Mommsen et al. (2016).

Petro-fabrics 4-6, each represented by a single sherd, were fossiliferous. The clays used for petrofabrics 4 and 5 are either naturally fine or have been worked to remove the coarser inclusions, whereas the clay used for petro-fabric 6 was not well-processed, with recurrent clay pellets and inhomogeneous clay areas (similar to petro-fabric 3). Petro-fabrics 4 and 6 were fired at lower temperatures than the first two petro-fabrics, below $750^{\circ} \mathrm{C}$, as the thin-walled microfossils are still intact and the fabric paste is birefringent (non-isotropic). AW221 (petro-fabric 5) was assigned to one of the NAA Cypriot groups, CypJ, and contains serpentine and amphibole, minerals which are common in the Cypriot Troodos Ophiolite. AW212 (petro-fabric 4) was not assigned to a group but was chemically generally similar to other NAA Cypriot groups. AW223 (petro-fabric 6) is a chemical outlier and was not assigned to an NAA group.

All of the Mycenaean sherds show similarities in surface treatment: they have well-polished surfaces, as seen in thin sections. After polishing they were painted. Even in unpainted areas, the polishing resulted in a shiny surface after firing. The pigments utilised were chemically different. Again, samples from sherds made from petro-fabrics 1-3 are similar in composition, whereas the pigments of petro-fabrics 5 and 6 are clearly different to each other and to those from the Peloponnesian sources (Figure 10). These variations in pigment are not directly correlated with the pottery fabrics: for example, the pigment with the highest calcium oxide content is not from the sherd with the highest calcium fabric, similarly for the pigment with the highest iron oxide content and its sherd fabric. In the Peloponnesian samples, iron oxide is only slightly higher in the pigment than in the fabric, and calcium oxide is always significantly higher in the fabric than in the pigment, but in petro-fabrics 5 and 6, iron oxide is much higher in the pigments than in the fabrics, and calcium oxide is either much higher in the fabric than in the pigment, or higher in the pigment than in the fabric. Thus while there seems to have been a regular pattern in the production of suitable pigments in the Peloponnese, the pigments used in Cyprus and an unknown site, probably outside the Peloponnese, were made using different formulae.

Like the variations in pigment composition, differences in firing temperature reflect the work of different artisans, with different skills, and possibly the use of different firing structures. The Peloponnesian ceramics were made by skilful artisans, who levigated their clays very thoroughly and mastered high firing temperatures. The Cypriot ceramics, on the other hand, were made by potters who did not take as much care to levigate their clays and did not appear to have as much control of the firing temperature.

\section{Conclusions}

In summary, the typological dates of the Mycenaean vessels are largely consistent with the occupation period of Amara West (c. 1300-1000 BC), although fragments from two vessels can be dated to the preceding ceramic phase (AW213/214, AW216/218) with their presence attesting to continued use, whether filled with imported Mycenaean perfumed oil, a local substitute or an entirely different liquid. 
While adding to the corpus of sites at which such vessels are known, this assemblage also included near-complete vessels found in modest dwellings: Mycenaean imports may not have solely been used in elite contexts. The petrographic and chemical analysis provides a nuanced picture of mainland manufacture, with differences in the preparation of the clay and chemical composition. This is likely to indicate different workshops and dates of manufacture in the northern Peloponnese.

The use of NAA and SEM-EDX provided different sets of data, which helped both to confirm the provenance attributions and to reveal variations in the methods used by different workshops to manufacture similar products, in particular the variety of paints used.

The scientific analysis also demonstrates that some vessels, of which only small fragments survive, had been produced in Cyprus. The analysis of fabric and paint helps to inform the NAA results, which assigned one sherd to a known Cypriot group and suggested that another was likely to be Cypriot. A third sherd (AW223) can be assigned to Cyprus on the basis of fabric. Although only a few Mycenaean vessels were imported at Amara West, their analyses help illustrate the complex network of production and trade in the Eastern Mediterranean during this period.

\section{Acknowledgements}

Fieldwork and analyses were funded by The Leverhulme Trust (2010-2014) and the Qatar-Sudan Archaeological Project (2014-2018), under the auspices of the National Corporation for Antiquities and Museums (Sudan); we are grateful to its Director General Dr. Abd el-Rahman Ali Mohamed, and to Shadia Abdu Rabo and Mohamed Saad, for facilitating this work and permitting the export of samples. Thanks are also due to the Egypt Exploration Society for permitting and facilitating the donation of Mycenaean sherds to the British Museum. The authors would like to thank Dr. Roberta Tomber (British Museum, UK), Dr John Meadows (ZBSA, Germany) and Dr. Penelope Mountjoy (British School at Athens, Greece) and two anonymous reviewers for their comments and discussion. The authors wish to thank also the staff of the research reactor of the Reactor Institute Delft, Delft University of Technology, for their technical support and A. Simpson (British Museum) for his help with some of the figures.

\section{References}

Beier Th, Mommsen, H (1994) Modified Mahalanobis filters for grouping pottery by chemical composition. Archaeometry 36:287-306

Budka J (2015) The Pharaonic town on Sai Island and its role in the urban landscape of New Kingdom Kush. Sudan \& Nubia 19:40-53

Buxeda I Garrigós J, Jones RE, Kilikoglou V, Levi ST, Maniatis Y, Mitchell J, Vagnetti L, Wardle KA, Andreou S (2003) Technology transfer at the periphery of the Mycenaean world: the cases of Mycenaean pottery found in Central Macedonia (Greece) and the Plain of Sybaris (Italy). Archaeometry 45(2):263-284

Buxeda I Garrigós J, Mommsen H, Tsolakidou A (2002) Alterations of Na, K and Rb concentrations in Mycenaean pottery and a proposed explanation using X-Ray Diffraction. Archaeometry 44(2):187-198 
Emery WB, Smith HS, Millard A (1979) The Fortress of Buhen: the Archaeological Report. Egypt Exploration Society, London

Fairman HW (1938) Preliminary Report on the Excavations at Sesebi (Sudla) and 'Amārah West, Anglo-Egyptian Sudan, 1937-8. Journal of Egyptian Archaeology 24(2):151-56

Furumark A (1941) The Mycenaean Pottery: Analysis and Classification. V. Petterson, Stockholm

Hankey V (1997) Aegean pottery at el-Amarna: shapes and decorative motifs. In: Phillips J (ed) Ancient Egypt, the Aegean, and the Near East: Studies in honour of Martha Rhoads Bell. Van Siclen Books, San Antonio, pp 193-218

Hammer O, Harper D, Ryan P (2001) PAST: Paleontological Statistics Software Package for Education and Data Analysis. Palaeontologia Electronica 4(1): online

Kelder JM (2010) The Egyptian Interest in Mycenaean Greece. Jaarbericht "Ex Oriente Lux" 42:125140

Kilikoglou V (1994) Scanning electron microscopy. In: Wilson DE, Day PM (eds.) Ceramic regionalism in prepalatial central Crete: the Mesara imports at EMI to EMIIA Knossos, Annual of the British School at Athens 89. British School at Athens, Athens, pp 1-87

Leonard A (1994) An Index to the Late Bronze Age Aegean Pottery from Syria-Palestine. Paul Åströms Forlag, Jonsered

Minault-Gout A, Thill F (2012) Saï II. Le cimetière des tombes hypogées du Nouvel Empire (SAC5). Fouilles de l'Institut français d'archéologie orientale 69. L'Institut français d'archéologie orientale, Cairo

Mommsen H (2011) Provenancing of Pottery. In: International Atomic Energy Agency (ed.), Nuclear Techniques for Cultural Heritage Research, IAEA Radiation Technology Series No. 2: 41-170. International Atomic Energy Agency, Vienna

Mommsen H, Kreuser A, Lewandowski E, Weber J (1991) Provenancing of pottery: A status report on Neutron Activation Analysis and Classification. In: Hughes M, Cowell M, Hook D (eds) Neutron Activation and Plasma Emission Spectrometric Analysis in Archaeology. British Museum Occ. Paper 82, London, pp $57-65$

Mommsen H, Beier T, Diehl U, Podzuweit Ch (1992) Provenance determination of Mycenaean sherds found in Tell el-Amarna by Neutron Activation Analysis. J Archaeol Sci 19: 295-302

Mommsen H, Sjöberg B L (2007) The importance of the 'best relative fit factor' when evaluating elemental concentration data of pottery demonstrated with Mycenaean sherds from Sinda, Cyprus. Archaeometry 49:357 - 369

Mommsen H, Bentz M, Boix A (2016) Provenance of red-figured pottery of the classical period excavated at Olympia. Archaeometry 58:371 - 379

Mountjoy PA (1986) Mycenaenan Decorated Pottery: A Guide to Identification. Paul Åströms Forlag, Jonsered

Mountjoy PA, Mommsen H (2001) Mycenaean Pottery from Qantir-Piramesse, Egypt. Annual of the British School at Athens 96:123-155

Mountjoy PA, Mommsen H (2015) Neutron Activation Analysis of Aegean-Style IIIC Pottery from 11 Cypriot and Various Near Eastern Sites. Egypt and the Levant 25:421-508

Müller V (2013) Die Verwaltung Nubiens im Neuen Reich. Meroitica, Schriften zur altsudanesischen Geschichte und Archäologie 18. Harrassowitz Verlag, Wiesbaden

Noll W, Holm R, Born L (1975) Painting of Ancient Ceramics. Angewandte Chemie International Edition, pp. 602-613 
Smith ST (2003) Wretched Kush: Ethnic Identities and Boundaries in Egypt's Nubian Empire.

Spataro M, Millet M, Spencer N (2015) The New Kingdom settlement of Amara West (Nubia, Sudan): mineralogical and chemical investigation of the ceramics. Archaeological and Anthropological Science 7(4):399-421

Spencer N (2014) Amara West: Considerations on Urban Life in Colonial Kush. In: Anderson JR, Welsby DA (eds) The Fourth Cataract and Beyond: Proceedings of the $12^{\text {th }}$ International Conference for Nubian Studies. Peeters, Leuven, Paris, Walpole MA, pp. 457-485

Spencer N (2017) Building on new ground: the foundation of a colonial centre at Amara West. In: Spencer N, Stevens A (eds) The New Kingdom in Nubia: Lived experience, pharaonic control and indigenous traditions. British Museum Publications on Egypt and Sudan 3. Peeters, Leuven, Paris, Walpole MA, pp 321-353

Spencer P (1997) Amara West I: The Architectural Report. Excavation Memoir 63. Egypt Exploration Society, London

Spencer P (2002) Amara West II: The Cemetery and the pottery corpus. Excavation Memoir 69. Egypt Exploration Society, London

Steindorff G (1937) Aniba, vol. II. JJ Augustin, Glückstadt

Van Wijngaarden GJ (2002). Use and Appreciation of Mycenaean Pottery in the Levant, Cyprus and Italy (1600-1200 BC). Amsterdam University Press, Amsterdam

Van Wijngaarden GJ (2011) Tokens of a Special Relationship? Mycenaeans and the Egyptians. In: Duistermaat K.and Regulski I (eds) Intercultural Contacts in the Ancient Mediterranean: Proceedings of the International Conference at the Netherlands-Flemish Institute in Cairo, $25^{\text {th }}$ to $29^{\text {th }}$ October 2008. Peeters, Leuven, Paris, Walpole MA, pp 225-251

\section{Captions \\ Figures \\ Figure 1. Map of Egypt and Nubia, showing findspots of Mycenaean vessels. Drawing: Claire Thorne.}

Figure 2. Key map of Amara West indicating distribution of Mycenaean sherds.

Figure 3. Mycenaean and Cypriot vessels and sherds grouped according to NAA results, with petrofabric groups indicated.

Figure 4. SEM BSE image of sample AW219 (petro-fabric 1, NAA group MYBE) showing vitrified clay filaments of the highly-fired fabric.

Figure 5. SEM BSE images of AW223 (petro-fabric 6, NAA: single) showing well-sintered clays, which were not vitrified, and well-preserved foraminifera with micritic and iron particles infilling the chambers.

Figure 6. Elemental map of sample AW227 (petro-fabric 1, NAA group MYBE) in thin section: a) BSE image of the mapped area $(\mathrm{x} 320 ; 0.37 \times 0.26 \mathrm{~mm}) ; \mathrm{b}-\mathrm{h})$ the concentration of seven elements: from very abundant (white) to absent (black, see legend).

Figure 7. Elemental map of the pigment and surface (a) of sample AW227 (petro-fabric 1, NAA group MYBE), showing (b) mapped area, (c-f) the concentration of four elements: from very abundant (white) to absent (black, see legend).

Figure 8. Result of a discriminant analysis of the 18 samples assuming three groups and including the four ungrouped samples. Plotted are the discriminant functions W1 and W2, which cover $74 \%$ and $26 \%$ of the between-group variance. The ellipses drawn are the $2 \sigma$ (standard deviation) boundaries of the groups. The different groups and the single samples are well separated. 
Figure 9. Principal Component Analysis of SEM-EDX bulk results, factors 1 and 2, which together account for $77.3 \%$ of variation. PCA was carried out on the correlation matrix of the averaged data of four bulk analyses per sample. Symbols represent petrographic fabrics (Table 2); labels include NAA grouping (Appendix 1).

Figure 10. Principal Component Analysis of SEM-EDX results of surface pigments, factors 1 and 2 , which together account for $81 \%$ of variation. Symbols represent petrographic fabrics (Table 2); labels include NAA grouping (Table 4).

Tables

Table 1. List of samples analysed and discussed in the paper. Phase IA: c.1300-1250 BC; IB: c. 1250 1210 BC; II: c. $1210-1180$ BC; III: c. $1180-1140$ BC; IV: c. 1140-1100 BC; V: c. 1100-1000 BC.

Table 2: Mineralogical description of petrographic fabric groups in Mycenaean-type pottery found at Amara West.

Table 3. SEM-EDX Compositional data from SEM-EDX results of four bulk analyses per sample at $\times 100$, with mean (blue rows) and standard deviation (white rows). Results are reported as normalised $\%$ oxides; b.d.l. = below detection limit.

Table 4. Compositional data from SEM-EDX analysis of the pigments identified on the surfaces of the Mycenaean samples (blue rows; mean of four bulk analyses) and standard deviation (white rows). Results are reported as normalised oxides; b.d.l. = below detection limit.

Appendix. Table: NAA results from the Mycenaean ceramics from Amara West, Sudan. 
Table 1

\begin{tabular}{|c|c|c|c|c|c|}
\hline $\begin{array}{l}\text { Petrographic } \\
\text { sample } \\
\text { number }\end{array}$ & $\begin{array}{l}\text { Object type/ ID } \\
\text { number }\end{array}$ & $\begin{array}{l}\text { Building } \\
\text { [Context] } \\
\text { (Phase) }\end{array}$ & Notes & NAA groups & $\begin{array}{l}\text { Petro- } \\
\text { fabric }\end{array}$ \\
\hline AW211 & $\begin{array}{l}\text { Stirrup jar } \\
\text { (C4536) }\end{array}$ & $\begin{array}{c}\text { E13.10 [5171] } \\
(\text { Phase IA) }\end{array}$ & Body, painted & $\begin{array}{l}\text { OlyA or MBKR } \\
\text { (Peloponnese) }\end{array}$ & 3 \\
\hline AW212 & $\begin{array}{l}\text { Stirrup jar } \\
\text { (C4535) }\end{array}$ & $\begin{array}{l}\text { E13.14.8 [5218] } \\
\quad(\text { Phase II) }\end{array}$ & False neck, painted & $\begin{array}{l}\text { single } \\
\text { (general } \\
\text { Cypriot) }\end{array}$ & 4 \\
\hline AW213 & $\begin{array}{l}\text { Pilgrim flask } \\
\text { (C4537) }\end{array}$ & $\begin{array}{c}\text { E13.8.4 [5130] } \\
\text { (Phase IIA) }\end{array}$ & $\begin{array}{l}\text { Body, painted. Shape FS } \\
\text { 189. Potential join with } \\
\text { AW214. }\end{array}$ & MBKR & 2 \\
\hline AW214 & $\begin{array}{l}\text { Pilgrim flask } \\
\text { (C4538) }\end{array}$ & $\begin{array}{c}\text { E13.15 [5047 and } \\
5049] \\
\text { (Phase IA-IB) }\end{array}$ & $\begin{array}{c}\text { Body, painted. Shape FS } \\
\text { 189. Potential join with } \\
\text { AW213. }\end{array}$ & MBKR & 2 \\
\hline AW215 & $\begin{array}{l}\text { Stirrup jar } \\
\text { (C3194) }\end{array}$ & \multirow{5}{*}{$\begin{array}{l}\text { D13.4.2 [3077] } \\
\quad(\text { Phase IA) }\end{array}$} & Body, painted & MBKK & 1 \\
\hline AW216 & $\begin{array}{l}\text { Stirrup jar } \\
\text { (C3206) }\end{array}$ & & $\begin{array}{l}\text { Large fragment ( } 9 \text { sherds } \\
\text { joined) including spout } \\
\text { and false neck. Painted. } \\
\text { Shape FS } 178 . \text { Same } \\
\text { vessel as AW } 218 .\end{array}$ & MYBE & 1 \\
\hline AW217 & $\begin{array}{l}\text { Stirrup jar } \\
\text { (C3207) }\end{array}$ & & False neck, painted & MBKK & 1 \\
\hline AW218 & $\begin{array}{l}\text { Stirrup jar } \\
\text { (C3208) }\end{array}$ & & $\begin{array}{c}\text { Fragment of body (11 } \\
\text { sherds), painted. Shape } \\
\text { FS 178. Same vessel as } \\
\text { AW } 216 .\end{array}$ & MYBE & 1 \\
\hline AW219 & $\begin{array}{l}\text { Stirrup jar } \\
\text { (C3209) }\end{array}$ & & $\begin{array}{c}\text { Fragment of body and } \\
\text { base (16 sherds joined). } \\
\text { Also false neck fragment } \\
\text { (2 sherds). Painted. } \\
\text { Shape FS } 180 .\end{array}$ & MYBE & 1 \\
\hline AW220 & $\begin{array}{l}\text { Stirrup jar } \\
\text { (C4691) }\end{array}$ & $\begin{array}{l}\text { E13.7.9 [5705] } \\
\text { (Phase IIA-IIB) }\end{array}$ & Body, painted & MBKK & 1 \\
\hline AW221 & $\begin{array}{l}\text { Stirrup jar } \\
\text { (C4692) }\end{array}$ & $\begin{array}{c}\text { E13.7.9 [5700] } \\
\text { (Phase IIB) }\end{array}$ & Body, painted & CypJ Co+ & 5 \\
\hline AW223 & $\begin{array}{l}\text { Stirrup jar } \\
\text { (C4862) }\end{array}$ & $\begin{array}{c}\text { E13.20.2 [10312] } \\
\text { (Phase IIB) }\end{array}$ & Body, painted. Burnt? & single & 6 \\
\hline AW224 & $\begin{array}{l}\text { Stirrup jar } \\
\text { (C4891) }\end{array}$ & $\begin{array}{c}\text { E13.22.3 [10465] } \\
\text { (Phase IIA) }\end{array}$ & Body, painted. Burnt & MBKR & 1 \\
\hline AW225 & $\begin{array}{l}\text { Stirrup jar } \\
\text { (C4890) }\end{array}$ & $\begin{array}{c}\text { E13.14.10 [10744] } \\
\text { (Phase IB/IIA) }\end{array}$ & Body, painted. Burnt & MBKR & $\begin{array}{c}1 \text { sub } \\
a\end{array}$ \\
\hline AW226 & $\begin{array}{c}\text { Stirrup jar (EES } \\
739 \mathrm{~h})\end{array}$ & $\begin{array}{c}\text { E12.3 } \\
\text { (EES Level 1-2 = } \\
\text { Phase II-IV) }\end{array}$ & Body, painted & MBKR & 1 \\
\hline AW227 & $\begin{array}{l}\text { Stirrup jar (EES } \\
\quad \text { BM 392) }\end{array}$ & $\begin{array}{c}\text { F14.7 } \\
\text { (phase unknown) }\end{array}$ & Body, painted & MYBE & 1 \\
\hline AW228 & $\begin{array}{c}\text { Stirrup jar (EES } \\
739 \mathrm{k})\end{array}$ & $\begin{array}{c}\text { D14.17 } \\
\text { (EES Level 2-3 = } \\
\text { Phase IB-II) }\end{array}$ & Handle, painted & MYBE & 1 \\
\hline AW229 & $\begin{array}{c}\text { Stirrup jar (EES } \\
7391)\end{array}$ & $\begin{array}{c}\text { D14.18 } \\
\text { (EES 'lowest level’ } \\
=\text { Phase IA/IB) }\end{array}$ & False neck, painted & MBKK & 1 \\
\hline
\end{tabular}

Phase IA: c.1300-1250 BC; IB: c. 1250-1210 BC; II: c. 1210-1180 BC; III: c. 1180-1140 BC; IV: c.

1140-1100 BC; V: c. 1100-1000 BC.

Table 1. List of samples analysed and discussed in the paper. 
Table 2. Mineralogical description of petrographic fabric groups in Mycenaean-type pottery from Amara West.

\begin{tabular}{|c|c|c|}
\hline $\begin{array}{l}\text { Fabric groups } \\
\text { and samples }\end{array}$ & $\begin{array}{l}\text { Clay and non-plastic } \\
\text { inclusions }\end{array}$ & Photomicrographs of thin sections \\
\hline Petro-fabric 1 & $\begin{array}{l}\text { Reddish, vitrified, calcareous } \\
\text { Abundant: iron oxides } \\
\text { Common: very fine and very } \\
\text { well-sorted quartz ( } 5-10 \% \text {; } \\
\text { typical size } 0.02 \mathrm{~mm} \text {; AW227 } \\
\text { contains few quartz } \\
\text { inclusions slightly coarser); } \\
\text { samples AW215, 216, 218, } \\
224 \text { are slightly richer in } \\
\text { quartz (<10\%; same size as } \\
\text { above) with slightly more } \\
\text { abundant muscovite } \\
\text { Rare: polycrystalline quartz, } \\
\text { plagioclase, fine muscovite } \\
\text { mica, ferruginous pellets } \\
\text { (AW216, 217, 220, 228, 229) }\end{array}$ & $\because 3$ \\
\hline $\begin{array}{l}\text { Petro-fabric } 1 \\
\text { Subgroup a }\end{array}$ & $\begin{array}{l}\text { Reddish, vitrified, calcareous } \\
\text { Similar to Group } 1 \text { but with } \\
\text { some possibly naturally } \\
\text { occurring siltstone fragments } \\
\text { (AW225) }\end{array}$ & \\
\hline Petro-fabric 2 & $\begin{array}{l}\text { Reddish, calcareous } \\
\text { Abundant: fine and well- } \\
\text { sorted quartz (<10\%; typical } \\
\text { size } 0.03 \mathrm{~mm}) \text {, iron oxides } \\
\text { Common: muscovite, } \\
\text { ferruginous pellets, opaques } \\
\text { Rare: sub-rounded } \\
\text { calcareous pellets with mica } \\
\text { (AW213,214) }\end{array}$ & \\
\hline Petro-fabric 3 & $\begin{array}{l}\text { Brown, calcareous } \\
\text { Abundant: fine limestone } \\
\text { fragments, quartz ( } 10 \% \text {; } \\
\text { typical size } 0.05 \mathrm{~mm} \text {, with } \\
\text { some coarser grains), clay } \\
\text { pellets. } \\
\text { Rare: fine muscovite mica, } \\
\text { polycrystalline quartz } \\
\text { (AW211) }\end{array}$ & \\
\hline
\end{tabular}




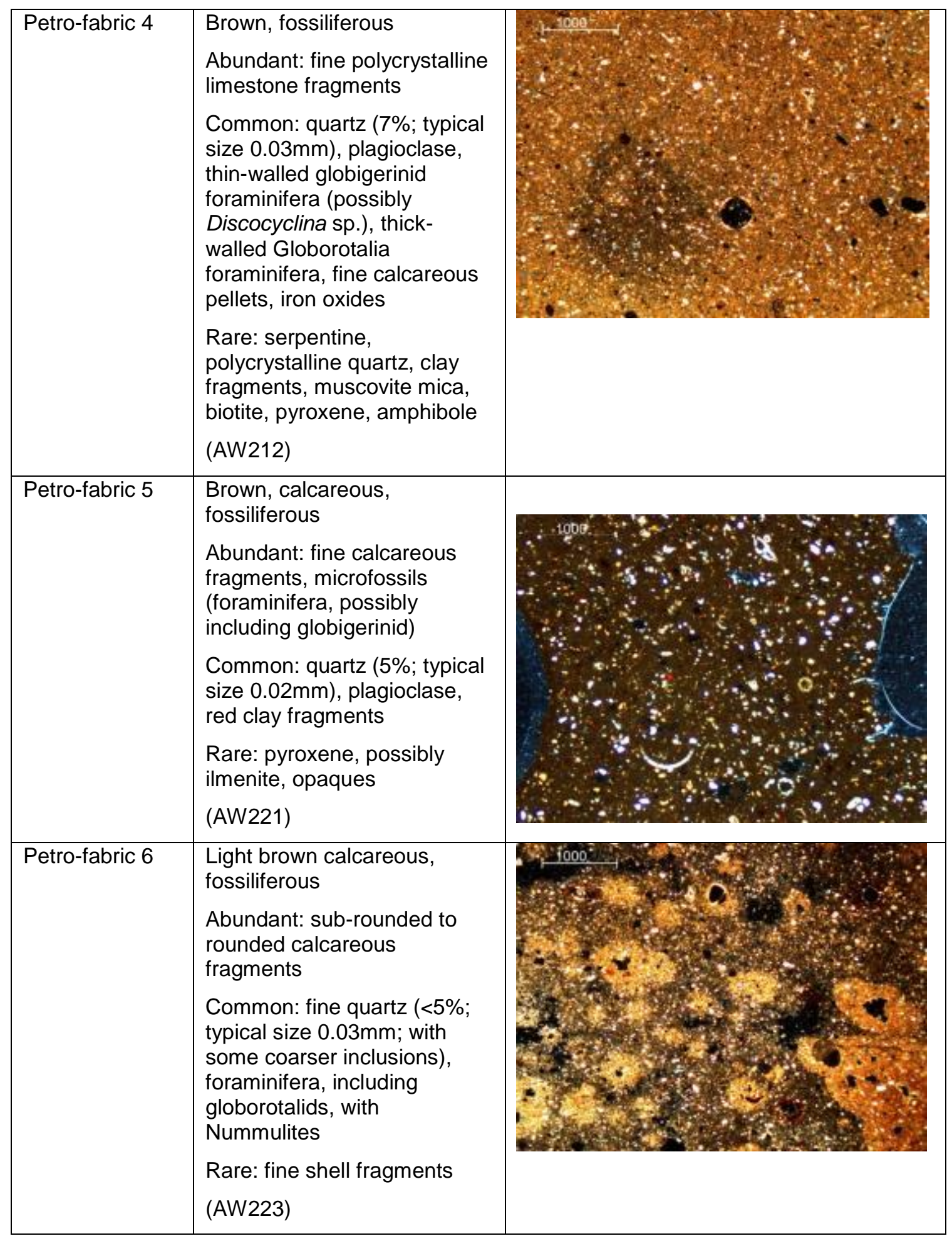


Table 3. SEM-EDX Compositional data from SEM-EDX results of four bulk analyses per sample at $\times 100$, with mean (blue rows) and standard deviation (white rows). Results are reported as normalised \% oxides; b.d.I. = below detection limit.

\begin{tabular}{|c|c|c|c|c|c|c|c|c|c|c|}
\hline Sample & $\mathrm{Na}_{2} \mathrm{O}$ & MgO & $\mathrm{Al}_{2} \mathrm{O}_{3}$ & $\mathrm{SiO}_{2}$ & $\mathrm{~K}_{2} \mathrm{O}$ & $\mathrm{CaO}$ & $\mathrm{TiO}_{2}$ & MnO & $\mathrm{FeO}$ & Petro-fabric \\
\hline AW215 & 1.80 & 4.20 & 17.40 & 52.80 & 1.40 & 14.80 & 0.80 & 0.10 & 6.70 & 1 \\
\hline s.d. & 0.10 & 0.00 & 0.20 & 0.30 & 0.00 & 0.20 & 0.00 & 0.00 & 0.20 & \\
\hline AW216 & 1.10 & 3.70 & 16.40 & 54.60 & 2.50 & 14.70 & 0.80 & b.d.I. & 6.20 & 1 \\
\hline s.d. & 0.00 & 0.10 & 0.10 & 0.50 & 0.10 & 0.30 & 0.00 & - & 0.10 & \\
\hline AW217 & 1.90 & 3.80 & 16.80 & 50.90 & 1.50 & 17.80 & 0.80 & b.d.I. & 6.50 & 1 \\
\hline s.d. & 0.10 & 0.00 & 0.20 & 0.30 & 0.10 & 0.20 & 0.00 & - & 0.10 & \\
\hline AW218 & 1.10 & 3.60 & 16.10 & 54.20 & 2.40 & 15.50 & 0.80 & 0.10 & 6.20 & 1 \\
\hline s.d. & 0.00 & 0.10 & 0.10 & 0.20 & 0.00 & 0.30 & 0.00 & 0.00 & 0.10 & \\
\hline AW219 & 0.90 & 4.00 & 17.60 & 52.80 & 2.90 & 14.00 & 0.80 & 0.10 & 6.70 & 1 \\
\hline s.d. & 0.00 & 0.10 & 0.20 & 0.30 & 0.10 & 0.10 & 0.00 & 0.00 & 0.10 & \\
\hline AW220 & 2.16 & 3.79 & 16.98 & 54.17 & 1.33 & 14.33 & 0.77 & 0.15 & 6.34 & 1 \\
\hline s.d. & 0.01 & 0.04 & 0.08 & 0.16 & 0.02 & 0.08 & 0.02 & 0.01 & 0.07 & \\
\hline AW224 & 1.23 & 3.31 & 16.24 & 55.00 & 2.68 & 14.70 & 0.74 & 0.14 & 5.99 & 1 \\
\hline s.d. & 0.04 & 0.10 & 0.13 & 0.27 & 0.13 & 0.50 & 0.01 & 0.02 & 0.15 & \\
\hline AW226 & 1.14 & 3.68 & 17.02 & 54.02 & 2.78 & 14.25 & 0.81 & 0.16 & 6.15 & 1 \\
\hline s.d. & 0.03 & 0.08 & 0.12 & 0.25 & 0.04 & 0.29 & 0.04 & 0.04 & 0.03 & \\
\hline AW227 & 0.98 & 3.92 & 17.45 & 54.60 & 2.99 & 12.72 & 0.79 & 0.13 & 6.44 & 1 \\
\hline s.d. & 0.03 & 0.04 & 0.05 & 0.44 & 0.05 & 0.27 & 0.06 & 0.02 & 0.14 & \\
\hline AW228 & 0.83 & 4.00 & 17.76 & 52.65 & 3.08 & 13.98 & 0.80 & 0.11 & 6.81 & 1 \\
\hline s.d. & 0.06 & 0.02 & 0.14 & 0.12 & 0.06 & 0.14 & 0.01 & 0.02 & 0.08 & \\
\hline AW229 & 2.26 & 3.94 & 16.93 & 52.21 & 0.91 & 16.43 & 0.71 & 0.13 & 6.50 & 1 \\
\hline s.d. & 0.08 & 0.07 & 0.13 & 0.36 & 0.06 & 0.32 & 0.04 & 0.01 & 0.07 & \\
\hline AW225 & 1.55 & 3.72 & 16.50 & 54.37 & 2.35 & 14.04 & 0.75 & 0.13 & 6.61 & 1 subgroup a \\
\hline s.d. & 0.02 & 0.04 & 0.20 & 0.17 & 0.07 & 0.11 & 0.06 & 0.04 & 0.03 & \\
\hline AW213 & 1.20 & 3.90 & 16.20 & 51.80 & 2.40 & 17.20 & 0.70 & 0.20 & 6.50 & 2 \\
\hline s.d. & 0.10 & 0.10 & 0.20 & 0.70 & 0.20 & 1.00 & 0.10 & 0.10 & 0.60 & \\
\hline AW214 & 1.00 & 3.80 & 16.80 & 52.50 & 2.60 & 16.00 & 0.80 & 0.10 & 6.40 & 2 \\
\hline s.d. & 0.00 & 0.10 & 0.10 & 0.40 & 0.10 & 0.40 & 0.00 & 0.00 & 0.10 & \\
\hline AW211 & 1.00 & 3.70 & 16.40 & 52.70 & 2.40 & 16.50 & 0.70 & 0.10 & 6.50 & 3 \\
\hline s.d. & 0.10 & 0.00 & 0.40 & 0.50 & 0.10 & 0.30 & 0.10 & 0.00 & 0.10 & \\
\hline AW212 & 2.10 & 6.10 & 12.00 & 44.60 & 3.20 & 25.60 & 0.60 & b.d.I. & 5.80 & 4 \\
\hline s.d. & 0.10 & 0.10 & 0.20 & 0.60 & 0.10 & 0.80 & 0.00 & - & 0.20 & \\
\hline AW221 & 2.37 & 4.75 & 14.57 & 56.39 & 2.24 & 12.79 & 0.79 & 0.17 & 5.95 & 5 \\
\hline s.d. & 0.09 & 0.18 & 0.13 & 0.24 & 0.05 & 0.49 & 0.08 & 0.02 & 0.31 & \\
\hline AW222 & 1.10 & 2.84 & 14.32 & 59.76 & 1.73 & 13.74 & 0.97 & 0.15 & 5.39 & 6 \\
\hline s.d. & 0.04 & 0.09 & 0.59 & 1.02 & 0.16 & 1.16 & 0.22 & 0.06 & 0.33 & \\
\hline AW223 & 1.29 & 5.41 & 9.28 & 36.00 & 1.94 & 42.06 & 0.52 & b.d.I. & 3.44 & 7 \\
\hline s.d. & 0.29 & 0.12 & 0.56 & 1.69 & 0.15 & 1.30 & 0.05 & - & 0.36 & \\
\hline
\end{tabular}


Table 4. Compositional data from SEM-EDX analysis of the pigments identified on the surfaces of the Mycenaean samples (blue rows; mean of four bulk analyses) and standard deviation (white rows). Results are reported as normalised oxides; b.d.l. = below detection limit.

\begin{tabular}{|c|c|c|c|c|c|c|c|c|c|c|c|}
\hline Pigments & $\mathrm{Na}_{2} \mathrm{O}$ & $\mathrm{MgO}$ & $\mathrm{Al}_{2} \mathrm{O}_{3}$ & $\mathrm{SiO}_{2}$ & $\mathrm{~K}_{2} \mathrm{O}$ & $\mathrm{CaO}$ & $\mathrm{TiO}_{2}$ & MnO & $\mathrm{FeO}$ & $\begin{array}{l}\text { Petro- } \\
\text { fabric }\end{array}$ & $\begin{array}{l}\text { Mommsen's } \\
\text { group }\end{array}$ \\
\hline AW211 & 0.60 & 2.20 & 26.80 & 52.20 & 4.20 & 4.90 & 0.70 & b.d.I. & 8.20 & 3 & $\begin{array}{c}\text { OlyA or MBKR } \\
\text { (1.10), AkaR } \\
\text { gen. } \\
\text { Peloponnese }\end{array}$ \\
\hline s.d. & 0.34 & 0.99 & 6.66 & 1.45 & 1.06 & 6.18 & 0.06 & - & 1.29 & & \\
\hline AW214 & 1.00 & 2.30 & 24.70 & 44.10 & 13.60 & 6.00 & 0.50 & 0.10 & 7.70 & 2 & MBKR \\
\hline s.d. & 0.08 & 0.14 & 0.54 & 0.92 & 0.29 & 0.21 & 0.06 & 0.04 & 0.91 & & \\
\hline AW221 & 3.60 & 3.00 & 19.80 & 39.80 & 1.40 & 21.00 & 0.60 & b.d.l. & 10.90 & 5 & CypJ-Co+ \\
\hline s.d. & 0.52 & 0.65 & 0.21 & 0.42 & 0.35 & 0.36 & 0.06 & - & 0.37 & & \\
\hline AW223 & 3.90 & 4.00 & 20.60 & 48.20 & 4.20 & 7.90 & 1.80 & 0.00 & 9.50 & 7 & single \\
\hline s.d. & 0.33 & 0.12 & 0.21 & 1.90 & 0.09 & 0.14 & 1.33 & 0.00 & 0.55 & & \\
\hline AW226 & 1.20 & 2.00 & 25.80 & 42.60 & 16.60 & 3.60 & 0.60 & b.d.l. & 7.60 & 1 & MBKR \\
\hline s.d. & 0.07 & 0.01 & 0.21 & 0.01 & 0.24 & 0.70 & 0.01 & - & 0.19 & & \\
\hline AW227 & 1.58 & 1.98 & 28.26 & 46.93 & 9.81 & 2.54 & 0.74 & b.d.I. & 8.14 & 1 & MYBE \\
\hline s.d. & 0.07 & 0.08 & 0.20 & 0.92 & 0.13 & 0.57 & 0.09 & - & 0.31 & & \\
\hline AW228 & 1.70 & 1.80 & 27.50 & 48.20 & 9.00 & 2.60 & 0.70 & 0.10 & 8.50 & 1 & MYBE \\
\hline s.d. & 0.58 & 0.04 & 0.28 & 1.33 & 1.53 & 0.60 & 0.03 & 0.02 & 0.02 & & \\
\hline AW229 & 1.70 & 1.60 & 26.70 & 54.20 & 6.40 & 1.80 & 0.60 & b.d.l. & 7.00 & 1 & MBKK \\
\hline s.d. & 0.81 & 0.85 & 5.29 & 6.48 & 5.09 & 0.48 & 0.31 & - & 3.81 & & \\
\hline
\end{tabular}




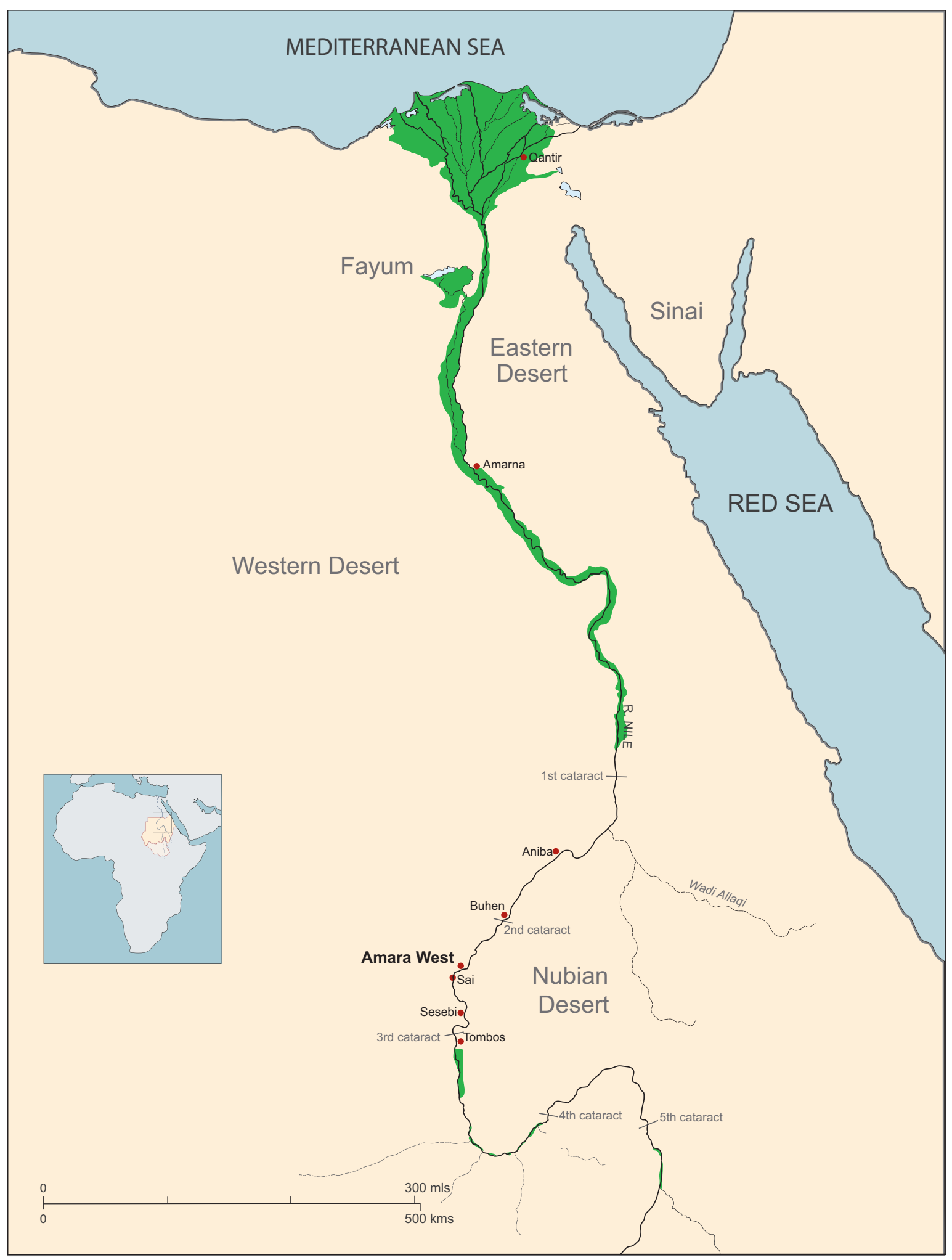




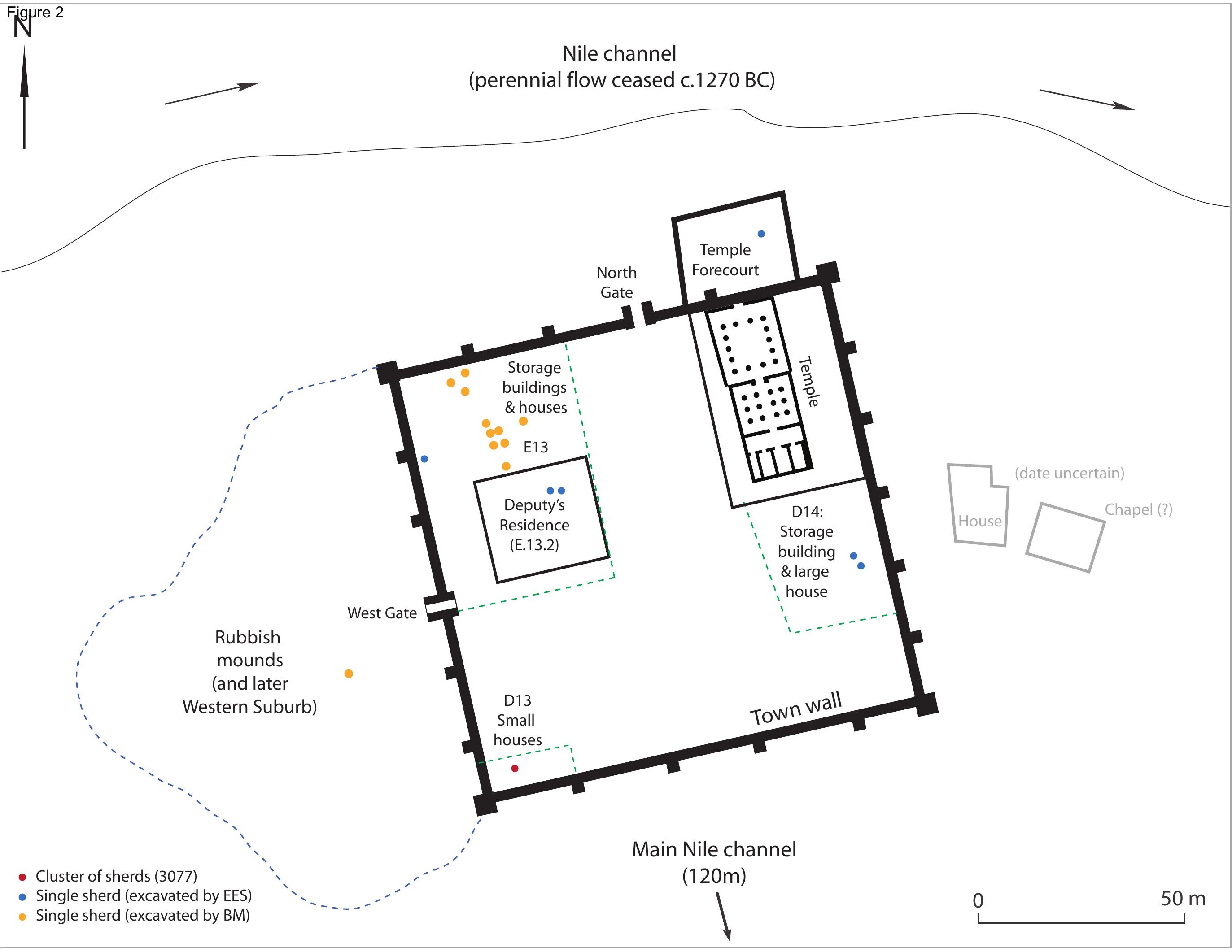




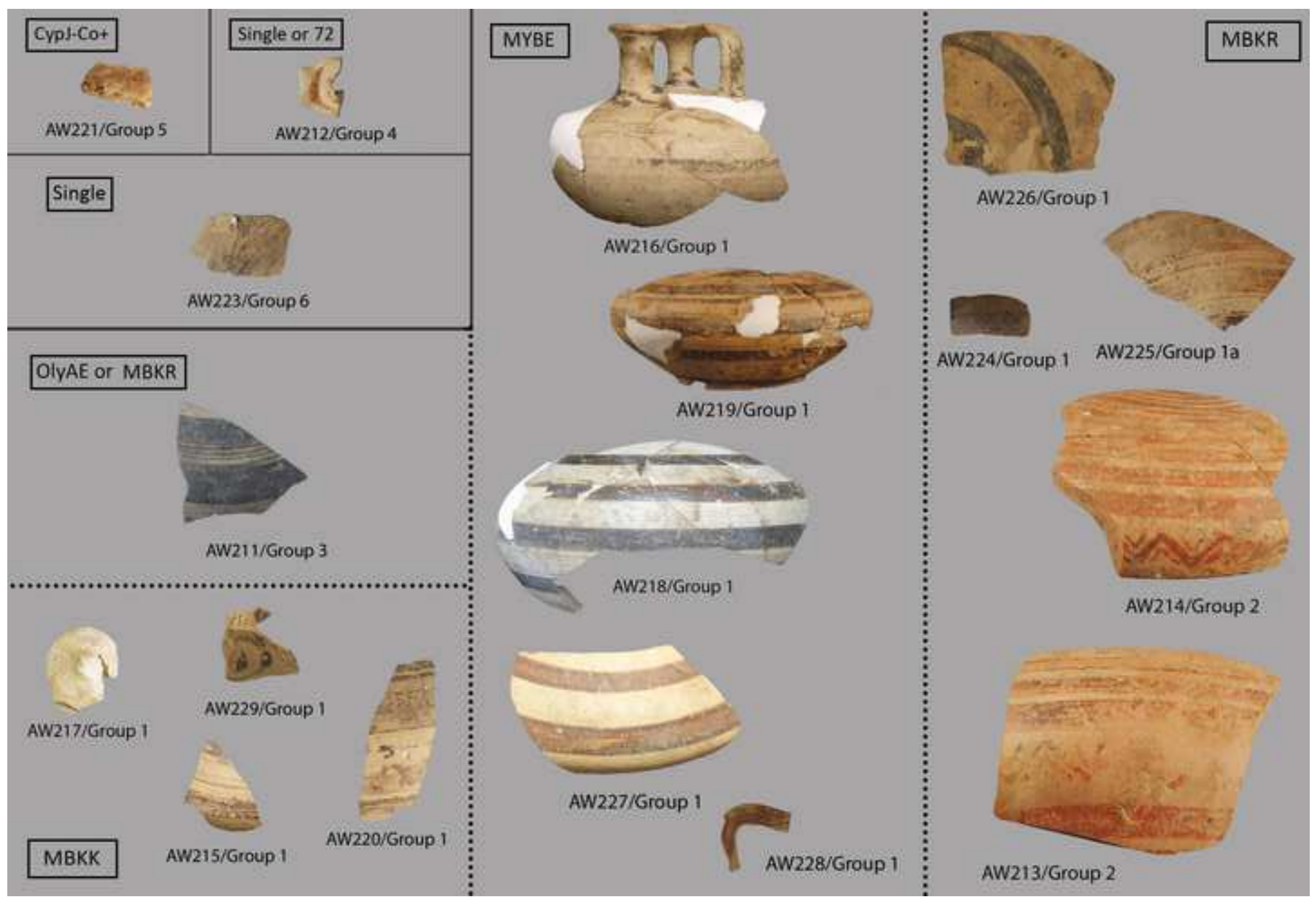




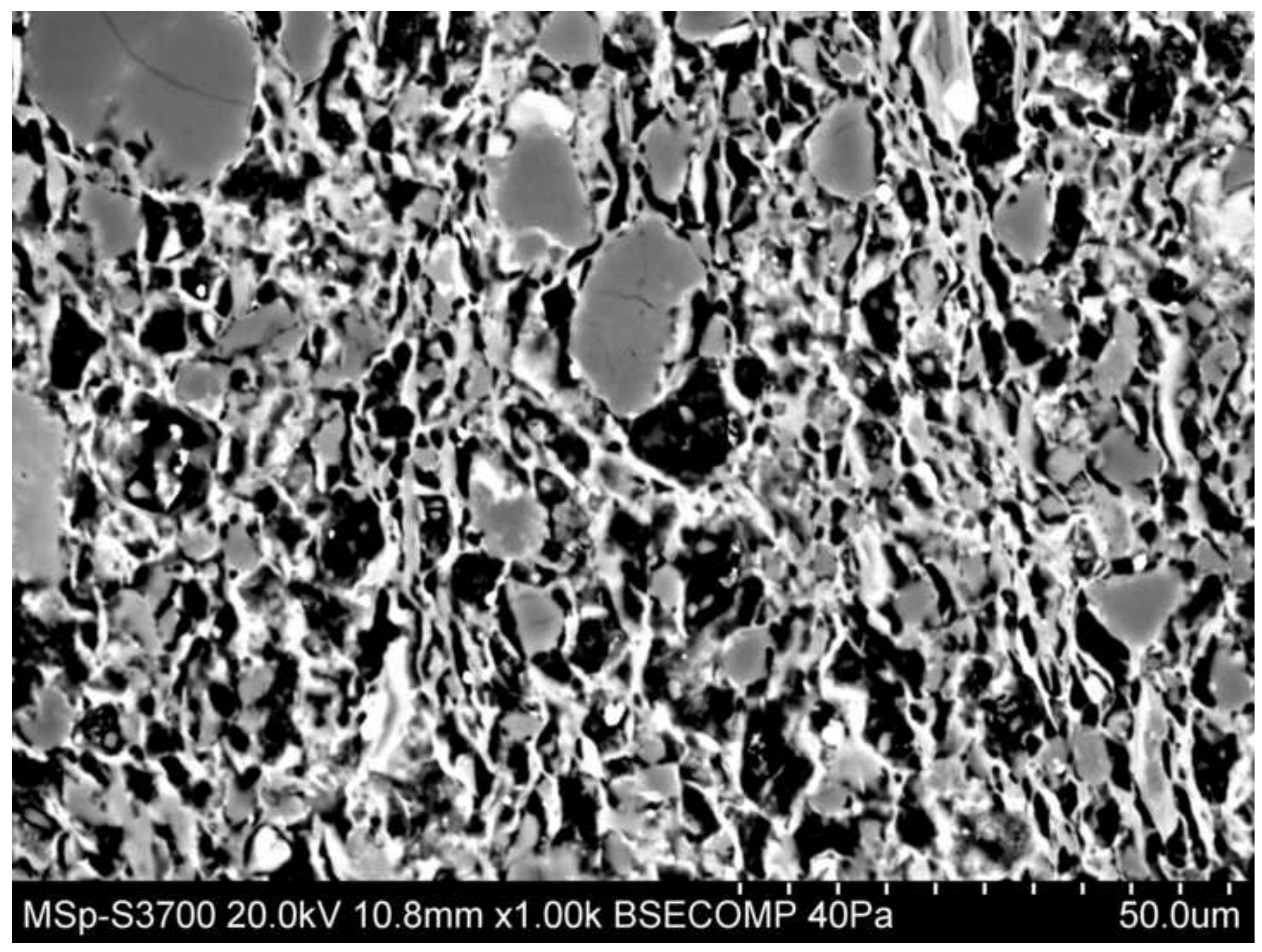




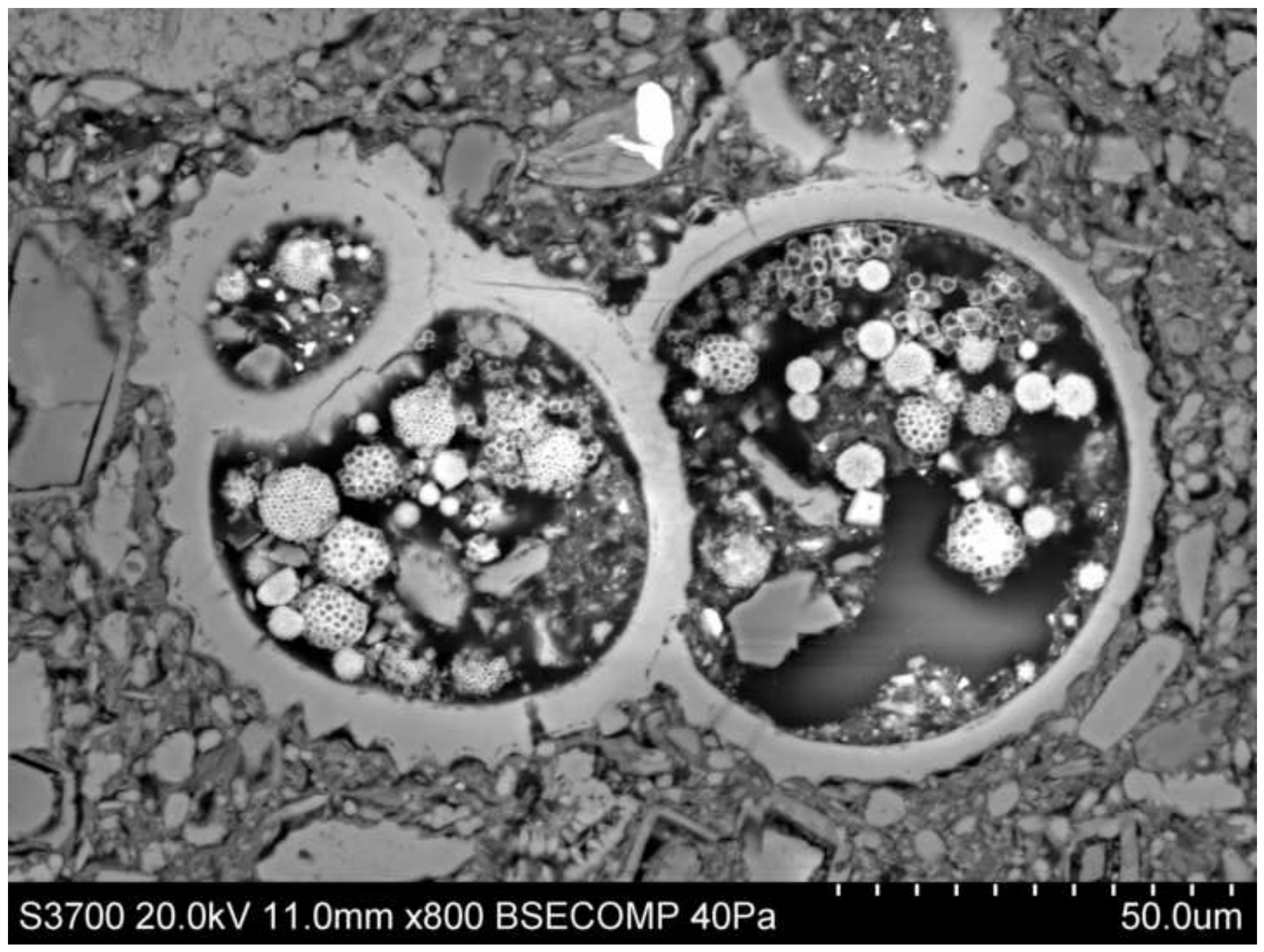



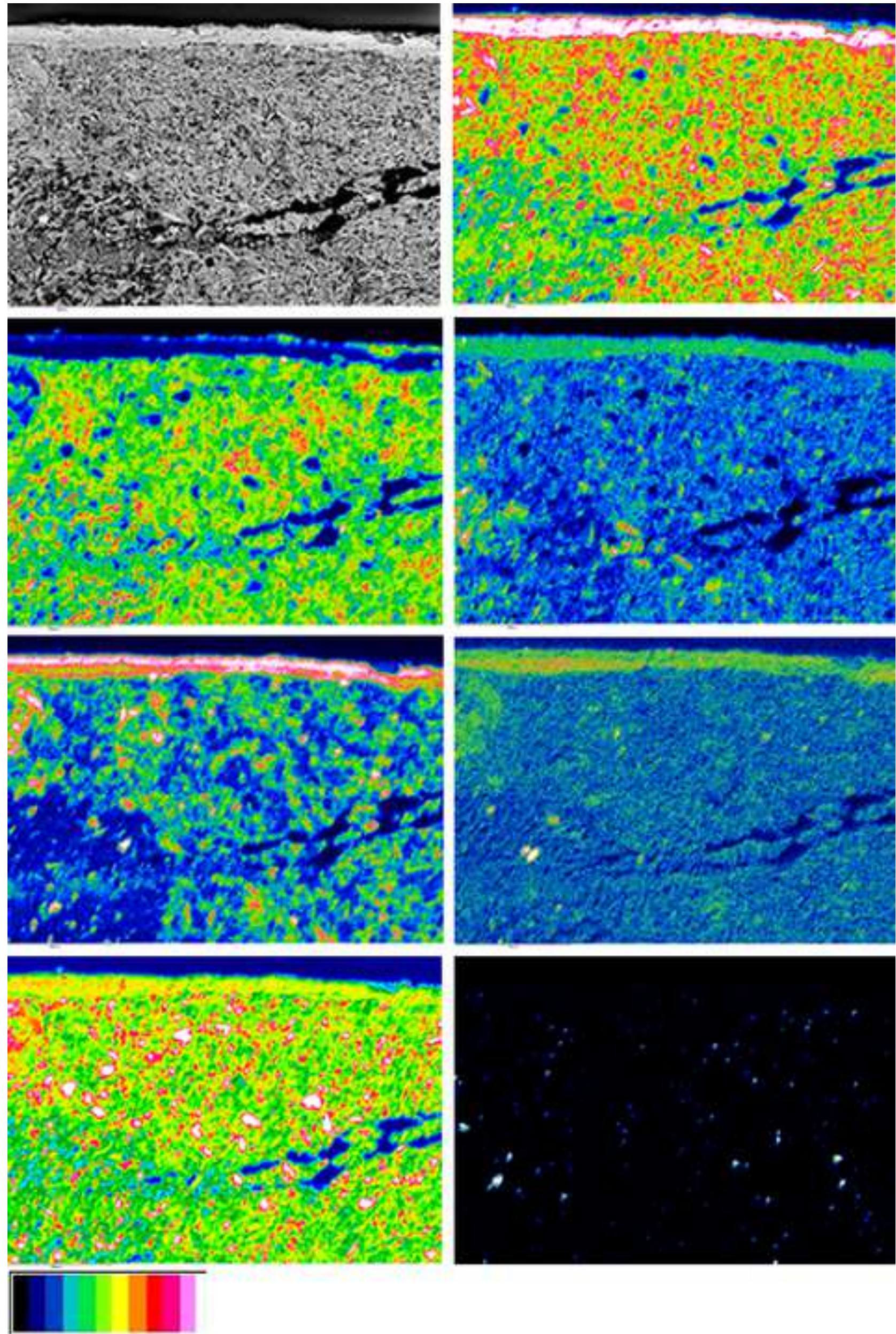

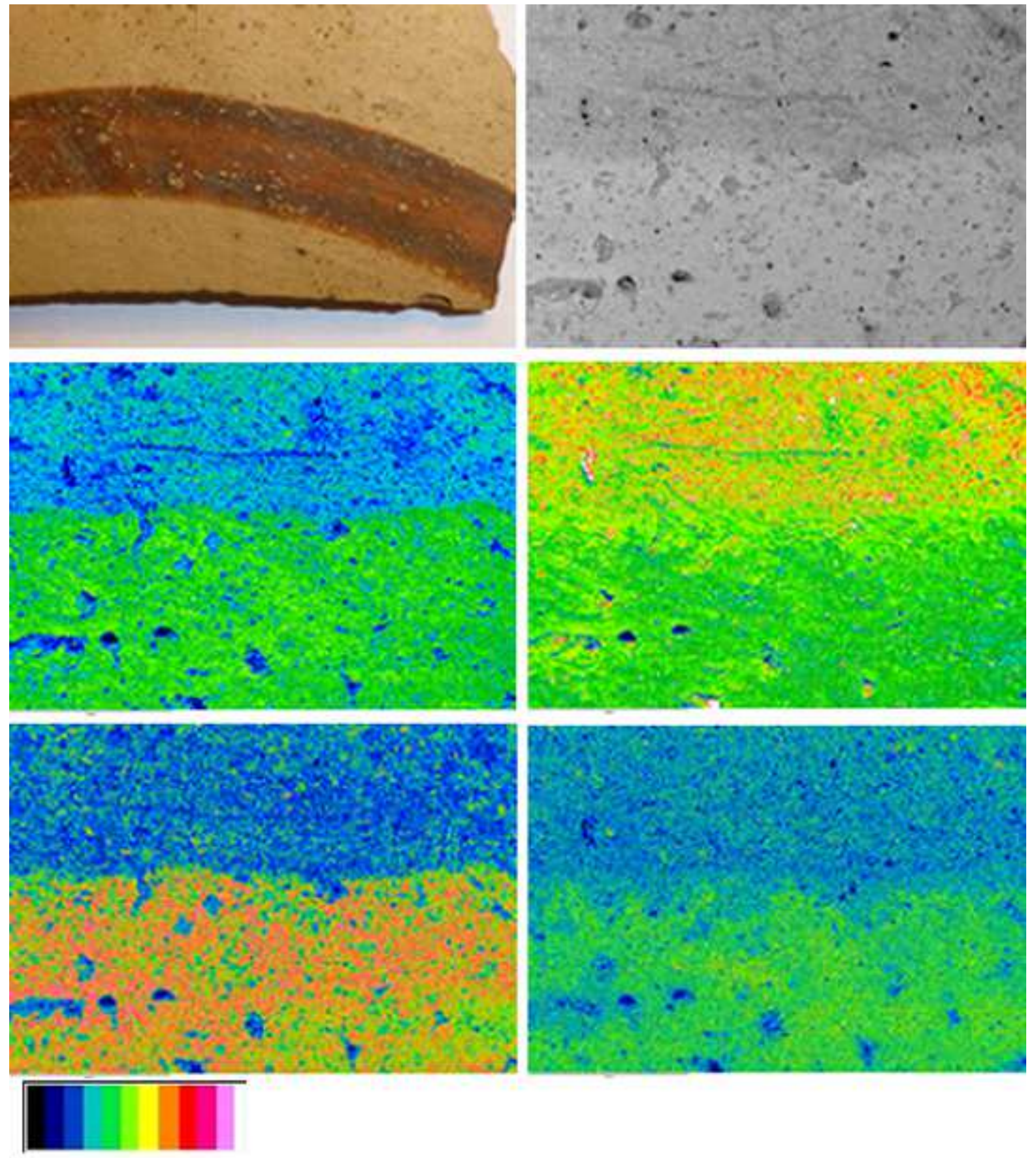


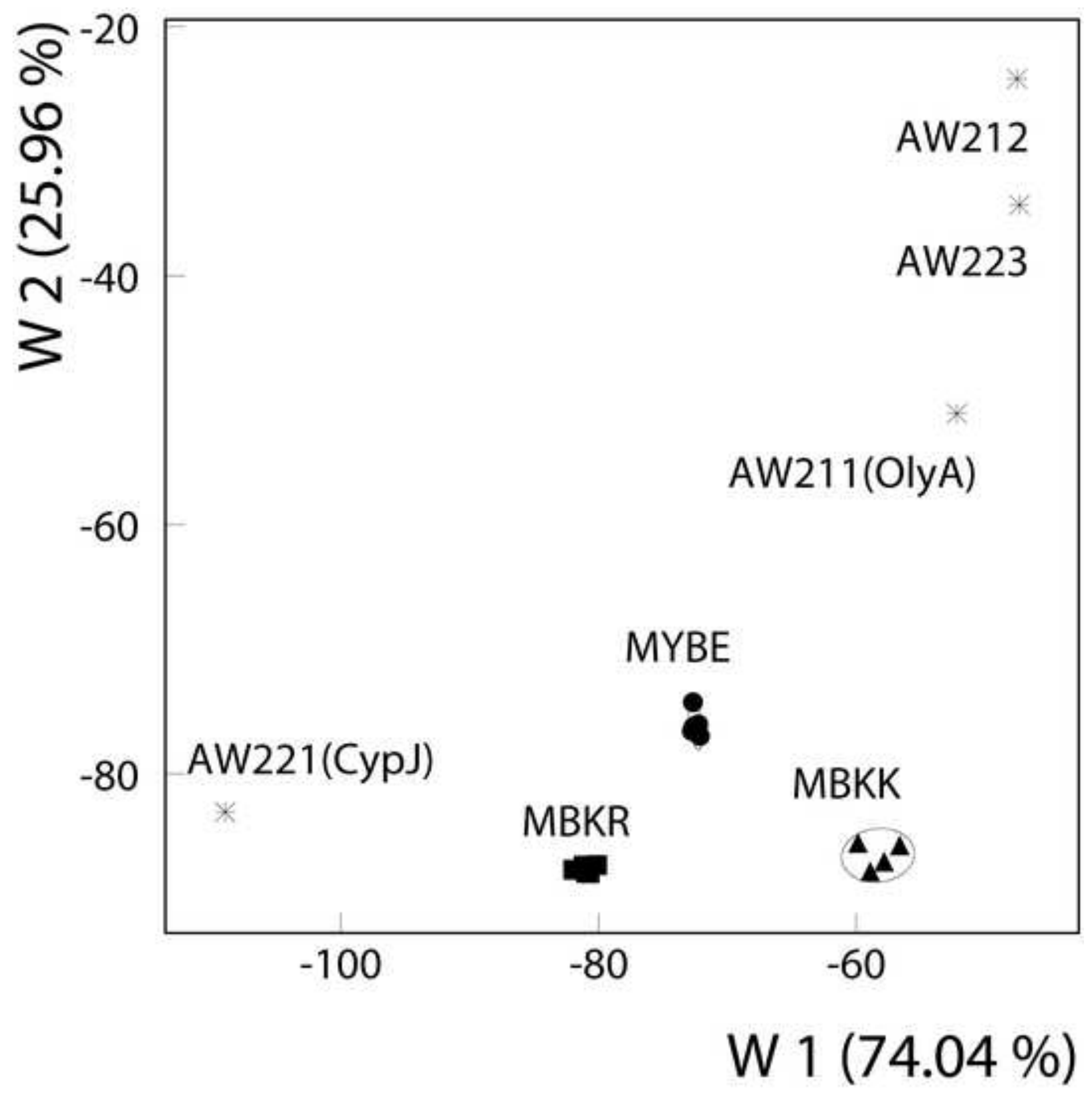


Legend

Petro-fabric

O 2

$\square$

- 4

$\triangle 5$

- 6

A AW212

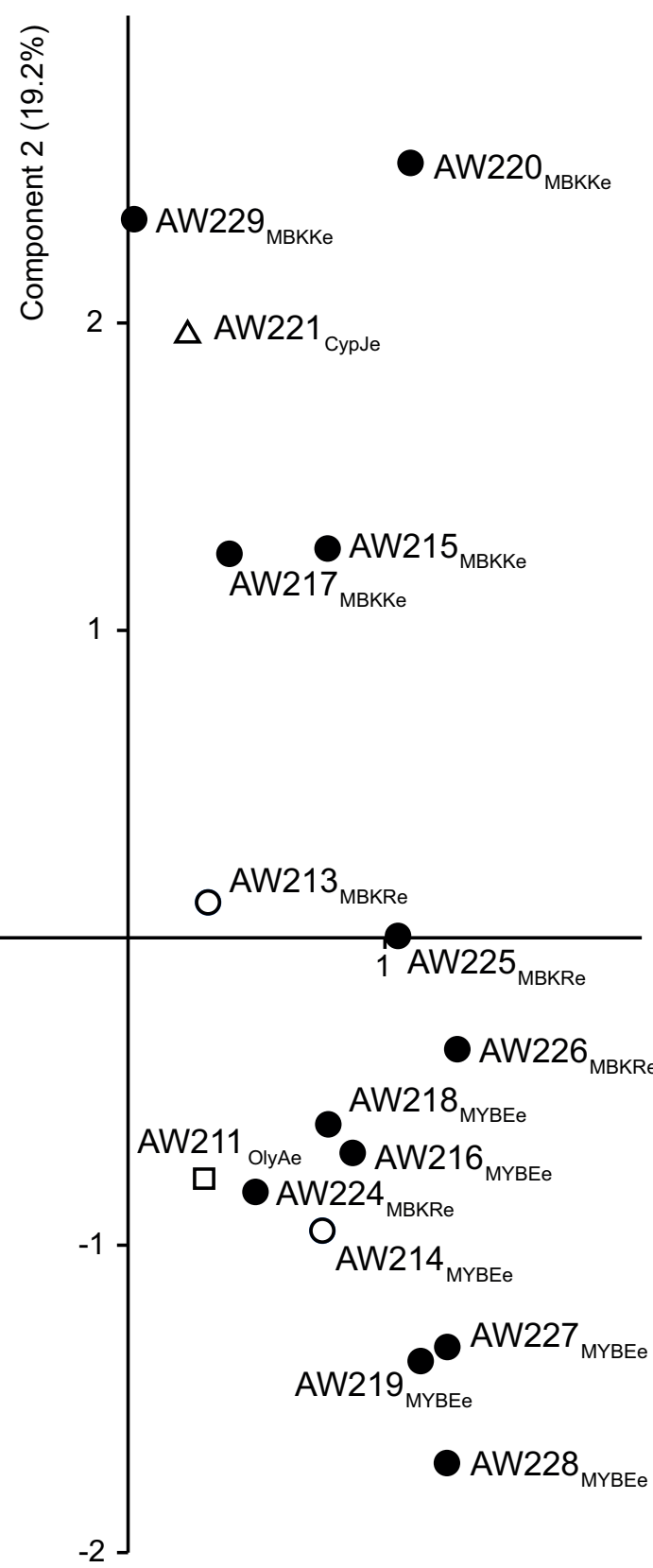


Figure 10

- AW229 ${ }_{\text {MBKKe }}$

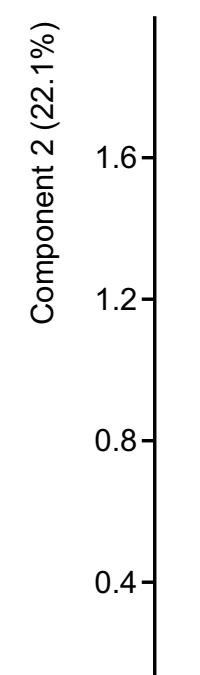

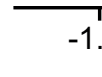

$-1.8$

$\square$ AW211 OlyA

- AW227 ${ }_{\text {MYBEe }}$

Component 1 (58.9\%)

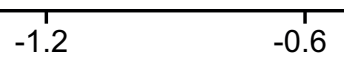

$-0.6$

- AW228 ${ }_{\text {MYBEe }}$

- AW226 ${ }_{\text {MBKR }}$

O AW214 ${ }_{\text {MYBEe }}$

$\left.\begin{array}{c}-0.4- \\ -0.8 \\ -1.2 \\ -1.6 \\ -2.0\end{array}\right]$

0

0.6

1.2

1.8

2.4

3.0

- AW223 ${ }_{\text {single }}$

$8-$ 2

$6-$

$\Delta_{\text {AW221 }}$ 
Click here to access/download Supplementary Material Spataro et al. Appendix 1.doc 